\title{
Posisi Ushul Fikih dalam Metodologi Ekonomi Islam
}

\author{
Wawan Gunawan Abdul Wahid \\ UIN Sunan Kalijaga \\ lignesgrises@gmail.com
}

\begin{abstract}
Abtraks:
Ekonomi Islam adalah suatu entitas pemikiran dan praktik yang saat ini menggeliat di tengah masyarakat Muslim. Setiap entitas pemikiran dipastikan memiliki metodologinya tersendiri. Demikian halnya dengan ekonomi Islam. Karena produk ekonomi Islam diniati sejak awal berbeda dari ekonomi konvensional, maka salah satu pembeda itu dipastikan dari kerangka fikir yang disebut ushul fikih. Tulisan ini menyajikan posisi ushul fikih dalam metodologi ekonomi Islam. Untuk menegaskan signifikansi posisi tersebut diperlihatkan beberapa misal produk ekonomi Islam dimana saat perspektif ushul fikih digunakan secara utuh memperlihatkan produk yang berbeda dari produk ekonomi konvensional.
\end{abstract}

Kata Kunci: Ushul Fikih, ekonomi Islam.

\begin{abstract}
:
Islamic Economics is an entity of thought and practice that currently writhing in Muslim communities. Each entity has certain ideas of its own methodology. So it is with Islamic economics. Since the product of intentional since the beginning of Islamic economics is different from the conventional economy was certainly one of the distinguishing framework called ushul fiqh. This paper presents the position of ushul fiqh methodology of Islamic economics. To confirm the significance of the position shown several such products where the Islamic economic jurisprudence fiqh perspective when used as a whole shows a different product than the product of conventional economics.
\end{abstract}

Keywords: Ushul Fikih, Islamic economics 


\section{Pendahuluan}

Perkembangan mutakhir menunjukkan bahwa ekonomi Islam, betapapun banyaknya varian yang terdapat di dalamnya, dirasakan eksistensi dan perannya di tengah ummat. Respon positif terhadap ekonomi Islam ditunjukkan juga dengan tiada hentinya perbincangan dan diskusi yang serius yang berkaitan dengan tema-tema dan topik yang terkait dengannya. Ini ditunjukkan dengan semakin semaraknya produk perbankan syariah di tengah masyarakat yang diikuti diskusi, seminar yang melibatkan para pemikir ekonomi Islam juga para praktisi. Salah satu bagian yang didiskusikan dalam ekonomi Islam adalah persoalan metodologi. Sebuah persoalan yang dinilai menjadi penanda yang membedakan antara suatu sistem ekonomi yang satu dengan sistem ekonomi lainnya. Dalam metodologi ekonomi Islam, al-Quran sebagai wahyu Allah dan as-sunnah sebagai model tuntunan dijadikan sebagai sumber yang mengilhami pandangan dunia Islamic man. Sebuah inspirasi yang memandu manusia muslim untuk, misalnya, menampilkan dirinya sebagai makhluk yang kreatif dalam rangka memenuhi kewajiban (kekhalifahan) di hadapan Allah dan sesama manusia. Dengan inspirasi al-Quran dan as-Sunnah, seorang islamic man manakala aktif bekerja selain untuk dirinya, iapun tidak mengabaikan orang lain bahkan ia bersifat altruis (Haneef: 59).

Persoalan metodologi mencakup masalah prosedur dan metode, yaitu proses dan cara yang mengantarkan lahirnya suatu produk pemikiran atau temuan ilmu pengetahuan. Jika ekonomi Islam diasumsikan sebagai produk kreatif manusia muslim yang dikembangkan dari fikih muamalah, maka mendiskusikan metodologi dalam ekonomi Islam tak dapat melepaskan diri dari peran ushul fikih. Bahkan Azizy menyatakan bahwa ekonomi Islam adalah fikih muamalat (Azizy, 2004: 175-199).

Karena itu menarik untuk membahas posisi ushul fikih dalam metologi ekonomi Islam. Makalah ini coba menyajikan posisi ushul fikih dalam metodologi ekonomi Islam. Untuk itu makalah ini akan diawali pembahasan pengertian metodologi ekonomi Islam yang disusul pembasan ushul fikih yang mencakup pengertian, fungsi dan beberapa hal terkait. Namun sebelumnya perlu disajikan sketsa revitalisasi ushul fikih 
sebagai bingkai bagi pemberdayaan kembali peran ushul fikih di era kontemporer.

\section{Metodologi Ekonomi Islam}

Dalam tradisi filsafat, metodologi merupakan bagian dari epistemologi (Surjasumantrin, 1982: 119). Dalam epistemologi (episteme dan logos), ada empat persoalan mendasar yaitu (1) hakekat pengetahuan; (2) sumber-sumber pegetahuan; metodologi ilmu tentang cara mengetahui pengetahuan; (3) sarana yang digunakan dalam biingkai kerja metodologi serta (4) uji kesahihan pengetahuan. Karena itulah epistemologi, antara lain, dimaknai sebagai ilmu (cabang filsafat) yang mempelajari sumber, struktur, metode dan kesahihan pengetahuan (Tim Dosen Filsafat UGM, 2002: 32).

Padanan kata untuk metodologi yang lazim digunakan dalam bahasa Arab adalah kata مناهج البحث (manahij al-bahts) (Majma' al-Lughah al-'Arabiyah, 1979: 306). Syami an-Nasysyar memberikan judul bukunya dengan Manahij al-Baths 'inda Mufakiril Islam ketika menyajikan buktibukti bagaimana para ilmuwan Muslim yang mencakup para ahli di bidang hukum, teologi, humaniora dan ilmu pasti menggunakan caracara untuk menemukan dan mendasarkan temuan mereka yang saat ini dikenal dengan metode ilmiah (an-Nasyar, 1984/1404).

\section{Karakteristik metodologi Ilmu Pengetahuan Islam}

Manakala disepakati bahwa memperbincangkan metodologi, antara lain, membahas prosedur dan metode ilmu pengethuan maka mendiskusikan metodologi berarti membicarakan proses dan metode-metode yang dengannya manusia dapat memperoleh pengetahuan tentang realitas. Karena itu pembahasan mengenai metodologi, pertama kali adalah pembahasan seputar manusia sebagai pelaku (subjek) pengetahuan.

Dalam metodologi Ilmu Pengetahuan Islam, ketika manusia menangkap ilmu pengetahuan ia melakukan itu dengan akalnya yang 
merupakan substansi spiritual yang bersumber dari Akal Ilahi. Dalam hal ini seluruh aspek kesadaran yang ada dalam diri manusia terlibat secara bersama-sama untuk berinteraksi dengan realitas dalam rangka meraih ilmu pengetahuan. Dalam hal ini para sarjana Islam sejak lama telah merumuskan bentuk metodologi Islam dalam berbagai kitab, antara lain al-Aqaid an-Nasafiyah yang disusun oleh 'Umar Najmuddin anNasafi yang dikomentari oleh Sa' duddin at-Taftazani. Disebutkan bahwa para sarjana Islam dalam meraih ilmu pengetahuan mengandalkan kepada sumber-sumber ilmu yang terdiri dari (1) al-khawas al-khamsah (pancaindera); (2) al-'aql as-salim (akal yangehat); dan (3) al-khabar ashshadiq (berita ang benar). Khabar shadiq kemudian dibagi lagi kepada dua bagian yaitu pertama, khabar mutawatir dan kedua khabar ar-rasul almuayyad bil mu'jizah.

Pengakuan panca-indera sebagai sumber ilmu pengetahuan menunjukkan bahwa metodologi Islam mengakui "empirical evidence" sebagai sumber ilmu. Dalam konteks ilmu ekonomi ini berarti bahwa buktibukti empiris yang menyokong suatu teori ekonomi tentu saja tidak akan ditolak oleh ekonomi Islam (Suharto, 2005: 3-4).

Ekonomi pada umumnya didefinisikan sebagai kajian tentang perilaku manusia dalam hubungannya dengan pemanfaatan sumbersumber prouduksi untuk menghasilkan barang dan jasa untuk didistribusikan dan dikonsumsi (Kahf, 1995: 3). Sedangkan definisi ekonomi Islam dituangkan oleh para ahli dalam beberapa ungkapan yang beragam sebagaimana terbaca berikut ini.

Hasanuz Zaman mendefinisikan ekonomi Islam sebagai "the knowledge and aplications and rules of the Syari'ah that prevent injustice in the requisition and disposal of material resources in order to provide satisfaction to human being and enabble them to perfom their obligation to Allah and the socieyt" (Zaman, 1984: 52). Sementara Syed Nawab Heider Naqvi menyatakan bahwa ekonomi Islam adalah "the representative Muslim's behavior in a typical Muslim society" (Naqvi, 1994: 18). Sedangkan ekonom Muslim M. Abdul Mannan mendefinisikan ekonomi Islam sebagai “ilmu pengetahuan sosial yang mempelajari masalah-masalah ekonomi yang diilhami oleh nilai-niai Islam" (Mannan, 1986: 6). 


\section{Peran Nilai dalam Metodologi Ekonomi Islam}

Ulama Muslim kontemporer asal Mesir Yusuf al-Qaradlawi menyebutkan empat akarakteristik ekonomi Islam. Keempat watak tersebut adalah ilahi, akhlaqi, insani dan tawassuth (Al-Qaradlawi, 1995/1415: 23-125).

Yang dimaksud dengan karakter ilahi adalah bahwa ekonomi Islam merupakan sebuah sistem yang menjadikan Allah sebagai tempat berangkat (mabda) dan menjadikan Allah tujuan akhirnya (ghayah). Misalnya, ketika manusia Muslim melakukan kegiatan produksi maka ia melakukannya karena memenuhi perintah Allah yang memenuhi prinsip halal dan thayib dalam rangka meraih kesyukuran untuk mendapat derajat taqwa. AlQaradlawi menguatkan pandangannya dengan beberapa nash al-Quran dan hadis Nabi menguatkan prinsip ini, antara lain, secara berurutan Surat al-Mulk (67) 15; al-Anfal (8) 26; al-Baqarah (2) 278-279.

Karena itu ketika ekonomi Islam dipraktekkan, ia memenuhi watak ekonomi akhlaqi yaitu ekonomi yang sarat dengan nilai-nilai luhur yang menyantuni kepentingan manusia untuk kehidupan manusia di sini dan nanti (duniawi dan ukhrawi). Karena pelaku ekonomi itu adalah manusia, maka Islam menambahkan karakter insani yang melekat pada dirinya. Watak insani dalam ekonomi Islam merupakan konsekwensi lanjut dari karakter ilahiy. Jika karakter ilahi itu menjadi sumber yang mengilhami maka karakter insani merupakan penerima yang mengejawantahkan nilai. Di antara nilai-nilai kemanusiaan yang dijunjung tinggi ajaran Islam adalah kemerdekaan, persaudaraan dan persamaan. Karena itu dalam karakteristik ini kemudian diturunkan kembali dalam prinsip-prinsip ekonomi Islam, khususnya dalam fiqh mu'amalat yang mencakup poin al-birru wat-taqwa dan al-musyarakah (Pradja, 1993:175-176). Sedangkan dimaksud dengan watak tawassuth adalah bahwa ekonomi Islam merupakan ekonomi moderat yang tidak memposisikan diri pada titik ekstrim tertentu. Nilai-nilai tersebutlah yang merasuk dan mewarnai pemikiran dan aktitifitas ekonomi Islam dan diyakini membedakannya dari ekonomi konvesional (Al-Qaradlawi, 1995/1415: 83-125).

Perangkat nilai ini digunakan dalam proses analisis dan dapat mempengaruhi metode melalaui (1) pemilihan praasumsi; (2) pemilihan 
topik analisis; (3) pemilihan variabel untuk dianalisis diantara sekian banyak variabel yang dipandang mempenagruhi fenomena serta (4) pemilihan metode dan kriteria untuk pengujian hipotesis (az-Zarqa, "Methodology of Islamic Economic" dalam Ahmad dan Awan (ed.), 1992: 51).

Contoh kasus pertama ketika dalam ekonomi diberlakukan banyak praanggapan dan pemilihan praanggapan mana yang digunakan ditentukan oleh sistem nilai yang dianut. Dalam ekonomi Islam sistem nilai itu tentu saja bersumber kepada wahyu Allah. Contoh kasus kedua yang berkaitaan dengan paham individualisme yang disadari atau tidak mengarahkan penelitian-penelitian yang dilakukan dalam kancah ekonomi kepada topik-topik ekonomi egoistik. Hal ini terjadi karena perhatian para ekonom konvensional terhadap perilaku altruistik nyaris tidak ada sama sekali. Ini dapat terjadi karena adanya sikap yang memandang bahwa perilaku altrusitik tidak penting dalam kehidupan nyata. Ada juga pendapat yang menyatakan bahwa hal demikian dikarenakan pandangan yang meyakini adanya invisible hand yang menyatakan bahwa setiap usaha individu dalam rangka memenuhi kepentingan dirinya secara tidak langsung pada akhirnya mensejahterakan masyarakat juga. Berbeda dengan pandangan tersebut Islam mengajarkan bahwa manusia dinilai (diasumsikan) memiliki dua potensi sekaligus yaitu egositik dan altruistik sedemikian rupa sehingga dalam ekonomi Islam analisis terhadap perilaku ekonomi diperluas cakupannya hingga ekonomi altrusitik.

Contoh kasus ketiga persoalan pertumbuhan ekonomi yang lazimnya dihubungkan dengan variabel investasi. Bebebrapa ahli ekonomi seperti Gunnar Myrdal menambahkan dua variabel lain yang diyakininya dapat mempengaruhi pertumbuhan di negara berkembang, yaitu variabel kelompok penekan dalam masyarakat yang melakukan perlawanan terhadap perubahan serta terjadinya korupsi dalam sektor publik. Contoh kasus yang keempat adalah berkaitan dengan pengutamaan penggunaan metode kuantitatif dalam beberapa analisis ekonomi. Studi terhadap kasus perindahan para pakar dari berbagai negara berkembang ke negara industri mengguanakan analisis ekonometrik dengan memasukan variabel ekonomi yang dapat diukur 
secara kuantitatif seperti tingkat penghasilan di negara asal, biaya perjalanan ke luar negeri sementara variabel lain diabaikan dengan alasan sulit untuk diukur secara kuantitatif seperti faktor-faktor sosial politik, faktor pribadi yang berhubungan dengan kesadaran nasionalisme, rasa memiliki terhadap negerinya seta tanggung jawab terhadap bangsanya.

\section{Definisi Ruang Lingkup dan Fungsi Ushul Fiqh}

Ushul fiqh terdiri dai dua kata ushul dan fiqh. Kata ushul (أصول) merupakan bentuk jamak dari ashl (أصل) yang secara bahasa berarti "sesuatu yang dibangun di atasnya sesuatu" (Maa Buniya 'alayhi dzalikasya-say-u). Secara terminologi kata ashl ini dipahami oleh para ahli sebagai ad-dalil. Sedangkan kata fiqh secara bahasa berarti al-'ilm atau al-fahm, memahami dan mengerti yang dalam pengertian ishtilah dimaknai sebagai "al'ilm bil-ahkam asy-syar'iyyah", pengetahuan tentang hukum-hukum syar'i (ad-Dawalibi, 1965/1385: 12).

Beragam pengertian yang disajikan para ahli tentang ushul fiqh. Berikut ini beberapa diantaranya dikemukakan oleh Abu Hamid al-Gazali dan Muhammad Abu Zahrah.

Abu Hamid al-Gazzali mendefinisikan ushul fiqh sebagai:

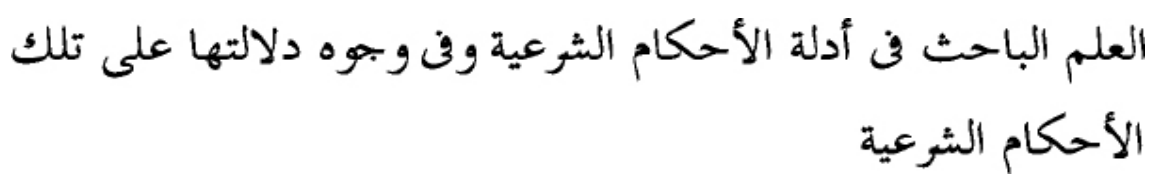

"Pengetahuan yang membahas tentang sumber-sumber hukum serta prosedur penunjukan sumber-sumber hukum tersebut pada hukum syar'i" (al-Gazzali, 1322, I: 5)

Muhammad Abu Zahrah mendefinisikan ushul fiqh sebagai berikut:

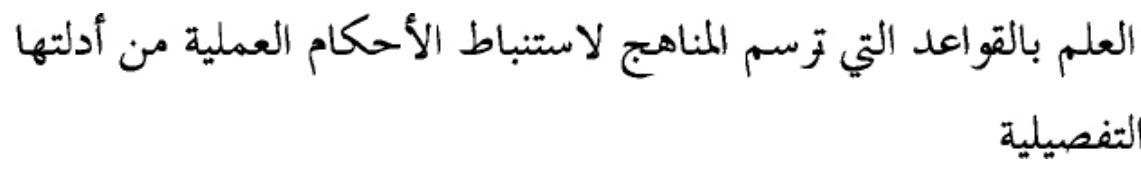

"pengetahuan tentang kaidah-kaidah yang menggambarkan metode-metode untuk menemukan hukum-hukum praktis dengan dalil-dalilnya yang rinci" (Zahrah, tt: 7). 
Dari definisi yang diekmukakan di atas selintas terbaca tiga macam objek kajian ushul fikih yang mencakup: (1). sumber hukum dengan berbagai aspek terkait; (2) metode penggunaan sumber hukum atau metode penggalian hukum dari sumbernya dan terakhir (3) persyaratan orang yang dinilai cakap untuk melakukan istinbath dengan segala cakupannya (Rahmat, 2007: 23).

Sementara itu, asy-Saukani dan al-Amidi menyebutkan bahwa objek kajian ushul fikih itu mencakup (al-Amidi, [1984], I: 9 dan asy-Syaukani, [1993]: 5):

1. Sumber-sumber hukum syara', baik yang disepakati seperti AlQur'an dan Sunah, maupun yang diperselisihkan, seperti istihsan dan mashlahah mursalah.

2. Pembahasan tentang ijtihad, yakni syarat-syarat dan sifat-sifat orang yang melakukan ijtihad.

3. Mencarikan jalan keluar dari dua dalil yang bertentangan secara zahir, ayat dengan ayat atau sunah dengan sunah, dan lain-lain baik dengan jalan pengompromian (al-jamu' wa at-taufiq), menguatkan salah satu (tarjih), pengguguran salah satu atau kedua dalil yang bertentangan (nasakh/tatsaqut Ad-dalilain).

4. Pembahasan hukum syara' yang meliputi syarat-syarat dan macammacamnya, baik yang bersifat tuntutan, larangan, pilihan atau keringanan (rukhsah). Juga dibahas tentang hukum, hakim, mahkum alaih (orang yang dibeban), dan lain-lain.

5. Pembahasan kaidah-kaidah yang digunakan dalam mengistinbath hukum dan cara menggunakannya.

Sedangkan Abu Hamid al-Gazzali, dalam kitabnya al-Mushtashfa min 'Ilm al-Ushul, al-Gazzali menyatakan bahwa ushul fiqh menjawab empat pertanyaan mendasar. Empat pertanyaan yang dijawab ushul fiqh adalah apakah hukum itu. Kedua, dimana hukum itu ditemukan. Ketiga, bagaimana cara untuk menemukan hukum. Keempat, siapa yang berhak untuk menemukan hukum dengan cara yang ditentukan dalam pertanyaan ketiga (al-Gazzali 1322, I: 7). 
Berdasarkan pengkajiannya pada beberapa literartur, Rahmat Syafei (2007: 24-25), menyebutkan bahwa fungsi ushul fikih adalah:

1. Memberikan pengertian dasar tentang kaidah-kaidah dan metodologi para ulama mujtahid dalam menggali hukum.

2. Menggambarkan persyaratan yang harus dimiliki seorang mujtahid, agar mampu menggali hukum syara' secara tepat, sedangkan bagi orang awam supaya lebih mantap dalam mengikuti pendapat yang dikemukakan oleh para mujtahid setelah mengetahui cara yang mereka gunakan untuk berijtihad.

3. Memberi bekal untuk menentukan hukum melalui berbagai persolan baru.

4. Memelihara agama dari penyimpangan dan penyalahgunaan dalil. Dengan berpedoman pada Ushul Fikih, hukun yang dihasilkan melalui ijtihad tetap dakui syara'.

5. Menyusun kaidah-kaidah umum (asas hukum) yang dapat dipakai untuk menetapkan berbagai persoalan dan fenomena sosial yang terus berkembang di masyarakat.

6. Mengetahui keunggulan dan kelemahan para mujatahid, sejalan dengan dalil yang mereka gunakan. Dengan demikian, para peminat hukum Islam (yang belum mampu berijtihad) dapat memilih pendapat mereka yang terkuat disertai alasan-alasan yang tepat.

Intelektual Muslim asal Syria, Wahbah az-Zuhayli (1986, I: 30-31), menyebutkan, ushul fiqh memiliki lima fungsi. Kelima fungsi ushul fiqh itu adalah: 1) fungsi historis (al-faidah at-tarikhiyah); 2) fungsi intelektual dan operasional (al-faidah al'ilmiyah wal 'amaliyah); 3) fungsi invensi (faidatuhu fil-ijtihad); 4) fungsi komparasi (faidatuhu fi majal al-muqaranah); 5) fungsi religi (al-faidah ad-diniyah).

Dari uraian definisi definisi ushul fikih serta berbagai fungsinya yang disajikan di atas kiranya terbaca bahwa ushul fikih memiliki titik singgung yang sama dalam hal fungsi-fungsi filsafat khususnya pada fungsi epistemologisnya. Jika filsafat memiliki tugas untuk mengantarkan penggunanya pada ajaran kebenaran maka ushul fikih bertugas mengantarkan penggunanya pada kebenaran pengetahuan tentang keabsah- 
an seuatu yang disimpulkannya.

Fungsi historis ushul fiqh menyajikan pembabakan sejarah perkembangan pemikiran dalam hukum Islam sejak periode kelahirannya pada masa Rasulullah saw, periode Sahabat, periode Tabi'in, periode penulisan ushul fiqh sebagai disiplin ilmu hingga periode kontemporer yang dapat digunakan. Dengan khazanah pemikiran para tokoh ushul fiqh dari masa ke masa itu bukan saja memandu pembelajar untuk menghargai khazanah klasik yang cerdas tetapi juga dapat digunakan sebagai bahan untuk mendesain masa depan yang lebih baik (wattakhthith limustaqbal afdlal fi dlaw turatsiha wa ushuliha wa muqaddasatiha). Fungsi inteletelek (faidah 'aqliyah) ushul fiqh berlaku bagi para mujtahid yang menjadikan ushul fiqh sebagai bekal intelektual dalam penemuan hukum. Sedangkan fungsi prakteknya (faidah 'amaliyah) berlaku untuk muqalid yang menjadikan ushul fiqh sebagai bahan anutan yang diyakini kegunaannya. Fungsi invensi (faidatuhu lil-ijtihad) berarti bahwa ushul fiqh membentangkan cara dan prosedur untuk yang memiliki kualifikasi mujtahid untuk menggunakan prosedur ushul fiqh untuk menemukan hukum Islam. Sedangkan dimaksud dengan fungsi komparasi ushul fiqh (faidatuhu lil-muqaranah) adalah ia membimbing para pembelajar untuk melakukan perbandingan diantara pendapat serta aliran-aliran yang berkembang dalam kalangan ushul fiqh sendiri atau menjadikan ushul fiqh sebagai bahan perbandingan dengan metode penemuan hukum konvensional. Terakhir fungsi religi (faidah diniyah) ushul fiqh bermakna bahwa ushul fiqh dapat memerankan fungsi keagamaan yang mendorong seseorang untuk menunaikan ajaran agamanya dengan baik. Terkait dengan fungsi terakhir ini para teoritisi ushul fiqh menyatakan bahwa "faidat ushulil figh ma'rifat ahkamillahi ta'ala wahiya sababul fawzi bissa'adat addiniyyah wad-dunyawiyah (az-Zuhayli,1986, I: 31).

Memperhatikan fungsi-fungsi usul fiqh sebagaimana disebutkan di atas dapat dipahami manakala Abu Ishaq asy-Syathibi mengatakan bahwa keberadaan ushul fiqh dalam kehidupan Muslim adalah sebuah keniscayaan yang tak dapat ditolak. Dua alasan dikemukakan asy-Syathibi tentang keqath'iyaan ushul fiqh. Pertama, bahwa seluruh simpulan hukum yang didasarkan pada sumber hukumnya (ushul fqihnya) mesti dilandasi 
pertimbangan yang qath'i. Kedua, dalam ushul fiqh pertimbangan rasional belaka tidak dapat dijadikan sebagai pertimbangan hukum karena akal hanya membantu naqal dalam penemuan hukum (asy-Syathibi, 1341, II: 211).

\section{Sumber dan Metode Penemuan Hukum Islam}

Al-Quran adalah sumber dari segala sumber hukum. Darinya ditimba hukum-hukum. Jika manusia mencitakan kemaslahatan hidup di sini dan nanti maka saat merumuskan hukum mesti menggunakan wawasan al-Quran. Karena itu hukum yang dibuat manusia Muslim tidakboleh bertenatngan dengan kaedah-kaedah hukum al-Quran. Bahwa alQuran merupaka sumber hukum yang utama dinatakan sendiri oleh ayat-ayat al-Quran sendiri yang menyebutkan lebih dari tigapuluh kali menyuruh umat Islam mematuhi Allah. Karena mematuhi Allah berarti mematui uacapan-uacapanNya yang antara lain dimuat dalam al-Quran. Hadis yang menceritaka bagaimana Rasululah mengji kesiapan Muadz bin Jabal ketika hendak diutus Rasulullah untuk menjadi hakim di negeri Yaman merupakan bukti bahwa al-Quran merupakan sumber hukum utama bagi umat Islam.

Al-Quran sebagai sumber utama hukum Islam hanya mengatur garis-garis besar berbagai aturan. Nabi saw sebagai penyampai ajaran al-Quran diberi otorias untuk menjelaskan apa yang telah diwahyukan kepadanya. Dengan demikian Rasulullah ia membawa tugas sebagai penjelas dan pelaksna apa yang difirmakan Allah dalam al-Quran. Dari sini dapat diakatakan bahwa as-Sunnah merupakan sumber hukum kedua setelah al-Quran. Nisbah as-Sunah terhadap al-Quran, menurut para ulama, ada 3 hal. Pertama, membertegas dan memperkuat apa yang telah ditetapkan al-Quran. Kedua, memperjelas dan merinci apa yang telah digariskan al-Quran dan ini yang paling dominan dari fungsi as-Sunnah. Ketiga, as-Sunah menetapkan hukum yang belum diatur oleh al-Quran (Khalaf, 1972: 39-40).

Secara garis besar ada dua metode penemuan hukum dalam ushul fikih. Pertama dinamakan metode literal (thariqah lafzhiyyah) yang kedua 
dinamakan metode ekstensifikasi (thariqah ma'nawiyah). Metode pertama menggunakan pendekatan kebahasaan sebagai basis landasannya sedangkan metode kedua menggunakan penalaran. Metode pertama digunakan ketika "membaca" al-Quran dan as-Sunnah sedangkan cara yang kedua digunakan manakala cara pertama tidak dapat dapat menyelesaikan persoalan hukum.

Di antara metode ekstensifikasi (thariqah ma'nawiyah) adalah qiyas, istihsan, istishlah. Qiyas basanya didefinisikan sebagai cara untuk menetapkan hukum yang kasusnya tidak ditemukan dalam nash al-Quran dan as-Sunnah dngan cara menyamakannya dengankasus yang terdapat dalam nash disebabkan kesamaan 'illat hukum (Khalaf, 1972: 84).

Istihsan biasanya dimaknai sebagai upaya untuk mentawaqufkan prinsip-prinisp umum dalam nash karena ditemukan nash lain yang menghendakinya. Karena itu secara terminologis istihsan biasa didefisikan sebagai berpalingnya seorang mujtahid dari qiyas yang tegas kepada qiyas yang tidak tegas. Keberpalingan mujtahid terpaksa dilakukan karena 'illat yang terdapat pada qiyas jali tidak atau kurang efektif jika dieksekusi sebaliknya pengaruh itu diyakini lebih kuat pada qiyas khafi.

Metode mashlahat murasalat adalah metode penetapan hukum yang kasusnya tidak diatur secara eksplisit dalam al-Quran dan asSunnah. Metode ini lahir sebagai kelanjutan dari pembagian mashlahat kepada tiga bagian yaitu mashlahat mu'tabarah, mashlahat mulghat dan mashlahat mursalah. Yang pertama yang ditegaskan oleh al-Quran dan as-Sunnah sedangkan yang kedua yang bertentangan dengan keduanya dan yang terakhir adalah mashalaht yang tidak ditegaskan oleh alQuran dan as-Sunnah juga tidak dilarang keduanya. Istilah lain yang biasa digunakan untuk metode ini adalah istishlah.

Ushul fikih melahirkan kaidah-kaidahnya yang khas yang kemudian dinamakan kaidah ushul. Sunnguhpun ada perbedaan yang kentar antara kaidah ushul dengan kaidah fikih namun masih banyak yang sulit ntuk membekannya. Para peneliti dalam bidang masing-masing menyatakan bahwa yang pertama kali membedakan antara keduanya adalah alQurafi yang menyatakan bahwa 'syariah itu ada dua hal yaitu ushul dan furu' sedangkan ushul terbagi dua yaitu ushul fikih dan kaidah-kaidah 
fikih kulliyah.

Lebih rini perbedaan antara keduailmu ini disebutka oleh Ali Ahmad an-Nadwi sebagai berikut:

Pertama, kaidah ushul adalah timbangan dan patokan untuk melakukan istinbath al-ahkam secara benar. Dengan ushul fikih digali hukum dari dalil-dalilnya seperti hukumasal kataperintah itu wajib katakata larangan menunjukkan arti larangan.

Kedua, kaidah ushul fikih meliputi semua bagian sedangkan kaidah fikih hanya bersifat aghlabiyah (pada mumnya) sehingga banyak sekali pegecualiannya.

Ketiga, kaidah ushul adalah cara untuk mengali hukum syara' yang praktis sedangkan kaidah fikih adalah kumpulan-kumpulan hukum yang serupa yang kembali kepada hukum yang sama.

Keempat, Kaidah-kaidah ushul muncul sebelum furu' sedangkan kaidah fikih muncul setelah uru'.

Kelima, kaidah-kaidah ushul menjelaskan masalah-masalah yang tekandung dalam berbagai macam dalil yang rinci yang memungkinkan dikeluarkan hkum dari dalil-dalil tersebut. Sedangkan kaidah fikih menjelaskan masalah fikih yan terhimpun dalam kaidah tadi (an-Nadwi, 1986/1406 H: 19).

\section{Peran Ushul Fikih dalam Pengembangan Ekonomi Islam}

Ketika menguraikan sub bab metodologi ekonomi Islam dalam bukunya al-Iqtishad al-Islami Usus wa Mabadi wa Ahdaf Abdullah Abdul Husain ath-Tahriqi menyatakan:

'Urgensi metodologi dalam ekonomi Islam tercermin pada digunakannya metode istinbath hukum dan penjelasan tentang hukum syar'i baik yang konstan (tsawabit) maupun yang berubah (mutaghayirat) untuk menganalisis persoalan-persoalan ekonomi. Seorang peneliti ekonomi Islam harus melakukan kajian yang mendalam entang syari' at supaya aktivitas ekonomi dengan berbagai variasinya sejalan dengan al-Quran dan as-Sunnah. Oleh karena itu usaha keras apapun yang 
dilakukan seorang peneliti ekonomi Islam tanpa memperhatikan nas, atau tanpa mengikuti cara yang telah ditetapkan para ulama fikih dan ushul fikih maka usaha tersebut tidak dapat dikategorikan sebagai ekonomi Islam (ath-Thariqi, 2004: 23-24).

Dengan terang pernyataan di atas menegaskan betapa ushul fikih sangat berperan dalam memastikan keabsahan suatu (produk) kegiatan ekonomi. Peran ushul fikih dalam ekonomi Islam dapat dilihat dengan jelas manakala melakukan pengkajian terhadap beberapa temuan ulama, baik yang klasik maupun yang kontemporer. Ketika para ulama menentukan keabsahan jual beli bai' al-wafa' (yaitu jual beli yang dilangsungkan dua pihak yang dibarengi dengan sarat bahwa barang yang dijual dapat dibeli kembali oleh si penjual manakala tenggang waktu yang disepakati telah tiba) (Dahlan, 1997, I: 176-9), asuransi, jual beli saham, multilevel marketing dan lain sebagainya. Mereka mencarikan sumber-sumber landasan kebolehan tersebut kepada al-Quran dan as-Sunnah serta metode ijtihad yang berlandaskan ruh kemashlahatan bagi kemanusiaan.

\section{Hukum Islam dan Perubahan Sosial}

Hukum tentang masyarakat mengatakan bahwa masyarakat senatiasa mengalami perubahan. Perubahan itu dapat berupa perubahan tatanan sosial, budaya, sosial ekonomi dan lain sebagainya. Dalam kaitan ini temuan para ahli linguistik dan semantik patut diperhatikan. Mereka berkesimpulan bahwa bahasa mengalami perubahan setiap sembilan puluh tahun. Perubahan dalam bahasa, secara langsung atau tidak langsung, mengandung arti perubahan pada masyarakat itu. Temuan ini menarik untuk diperhatikan sebab "berarsiran" dengan hadis Nabi Muhammad saw yang menyebutkan bahwa setiap searatus tahun (seabad) akan ada orang yang bertugas memperbaharui pemahaman keagamaan. Pernyataan Nabi itu sejalan dengan hasil penelitian dari para ahli linguistik dan semantik itu.

Jika teori di atas digunakan berarti sejak Nabi saw wafat, umat Islam telah mengalami perubahan sebanyak lima belas kali. Pada setiap abad mestinya terdapat seorang mujaddid atau seorang mujtahid. Orang itu 
harus bisa menyelesaikan masalah pada zamannya. Hal ini berarti bahwa ijtihad para ulama terdahulu mesti sesuai dengan waktu dan keadaan di mana mereka berada, namun belum tentu sesuai dengan keadaan umat Islam sekarang ini. Dalam hubungan ini pernyataan Ibnu Qayyim al-Jauziyyah mendapatkan momentumnya ketia ia mengatakan:

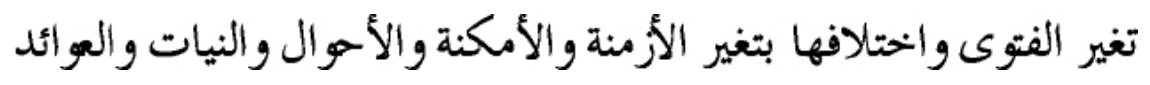

"Perubahan fatwa adalah karena perubahan zaman, tempat, keadaan, niat dan kebiasaan". (al-Jauziyah, tt., III: 14).

Pernyataan di atas memaksudkan bahwa kondisi suatu masyarakat berpengaruh terhadap fatwa yang dikeluarkan oleh seorang mufti tetapi tidak berarti bahwa hukum akan berubah begitu saja, tanpa memperhatikan norma yang terdapat dalam sumber utama hukum Islam, AlQur'an dan Hadits.

Sejarah mencatat, bahwa ijtihad telah dilaksanakan dari masa ke masa. Pada awal Islam, ijtihad telah dilakukan dengan baik dan kreatif. Pada masa berikutnya muncul sederetan mujtahid kenamaan. Keadaan ini berlansung sampai masa keemasan umat Islam. Pada masa inilah telah dihasilkan pemikiran dan karya yang cukup berharga bagi umat Islam berikutnya. Ilmi fikih dan ushul fikih termasuk yang dihasilkan pada masa ini. Setelah diselingi oleh masa "beku", kemudian bermunculan pula para pembaharu dan mujtahid untuk menyelesaikan persoalan yang timbul pada masanya. Kalaulah pada masa lampau mujtahid didambakan keberadaanya oleh umat Islam, maka sekarang keberadaanya sangat diharapkan.

Penghargaan terhadap mujahid masa lalu dapat dilakukan dengan menghargai hasil karya dan jerih payah mereka yang telah menuangkan pikirannya dalam berbagai buku yang sangat banyak jumlahnya. Apresiasi ini disertai dengan kesadaran bahwa situasi yang melingkupi para ulama terdahulu berbeda dengan keadaan kiwari. Karenanya dapatlah dikatakan bahwa tidak semua persoalan yang dihadapi manusia kontemporer dapat ditemukan jawabannya pada buku-buku peninggalan mereka. Dalam hubungan ini Yusur al-Qaradlawi, misalnya, pernah menyatakan: 
Adalah suatu hal yang berlebihan dan juga merupakan sikap purapura yang tidak mengenal kenyataan, manakala seseorang mengatakan bahwa buku-buku lama telah memuat jawaban-jawaban atas setiap persoalan yang baru muncul. Sebab setiap zaman itu memiliki problematika dan kebutuhan yang senatiasa muncul. Bumi berputar, cakrawala bergerak, dunia berjalan dan jarum jam pun tidak pernah berhenti (al-Qaradlawi, 1985: 101).

Karena itu, upaya-upaya kreatif dalam hukum Islam pada masa sekarang ini jauh lebih diperlukan dibandingkan masa-masa lampau. Berbagai persoalan kontemporer telah muncul ke permukaan dan menuntut solusinya. Persoalan-persoalan tersebut meliputi berbagai bidang kehidupan, mulai dari persoalan sosial budaya, masalah rekayasa genetika dalam bidang ilmu kedokteran hingga produk-produk terbaru dalam bidang ekonomi.

Dalam bidang ekonomi saatini dijumpai beberapa kegiatan atau lembaga yang dahulu tidak ada. Lembaga perbankan dengan segala kaitannya, lembaga asuransi dengan segala macamnya, merupakan masalah yang harus dilihat hukumnya dalam Islam.

Patut diakui bahwa beberapa masalah yang muncul sekarang ini, secara kebetulan, mirip atau bahkan sama dengan masalah-masalah yang telah dibahas oleh para ahli fikih terdahulu. Terhadap kasus semacam ini, mujtahid sekarang bekewajiban untuk mempelajari dan meninjau kembali masalah-masalah yang telah ditetapkan hukumnya, kemudian menyesuaikannya dengan kondisi dan kebutuhan kekinian. Semangat itu sejalan dengan kaidah yang menyatakan:

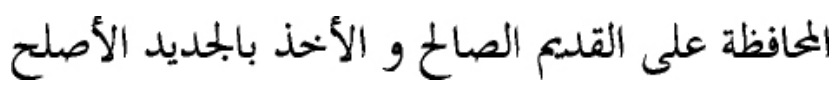

"Memelihara yang lama yang masih kompatibel (dengan kekinian) baik, dan mengambil yang baru yang lebih baik.

A Djazuli memasukkan kaidah ini dalam kaidah-kaidah fikih yang menjadi landasan kemungkinan pengembangan kaidah fikih sebagai bingkai jawaban persoalan kontemporer (Djazuli, 2006: 193).

Sedangkan mengenai masalah-masalah yang sama sekali baru, 
mujtahid pada masa sekarang ini harus menyelesaikannya dengan cara memahami secara baik masalah dimaskud kemudian mendiskusikannya secara seksama dengan tetap merujukkannya pada jiwa hukum Islam yang terkandung dalam Al-Qur'an dan Hadis serta metode ijtihad yang dipandang relevan dengan kekinian.

Dua kaidah tersebut berbunyi (As-Suyuthi, tt: 43-44):

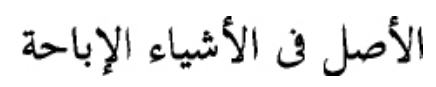

Prinsip dalam segala sesuatu adalah boleh.

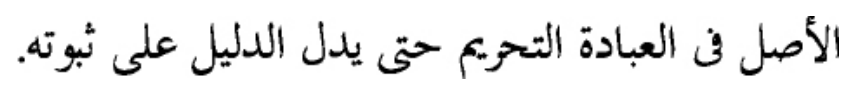

Prinsip dalam persoalan ibadah itu adalah haram sampai ada dalil menyatakan ketetapannya.

Kedua kaidah tadi digabungkan oleh Abu Ishaq asy-Syathibi $(1341 \mathrm{H}$, II: 211) dengan rumusannya yang terkenal:

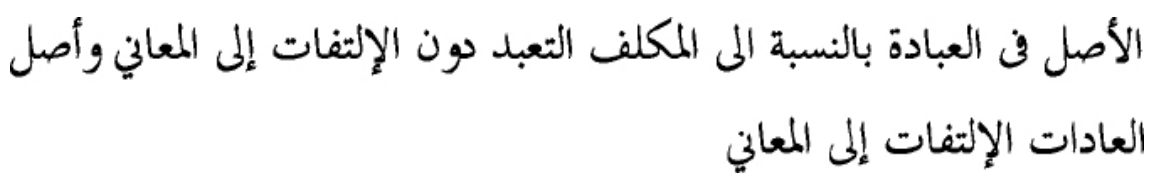

Prinsip persoalan ibadat bagi pelaku hukum (mukallaf) ialah ta'abbudi tanpa peluru melihat pada nilai, sedangkan prinsip persoalan adat (mu'amalat) ialah melihat pada nilai.

Islam menyadari bahwa kehidupan dan pola hidup serta kebutuhan manusia selalu berkembang sesuai dengan perkembangan waktu dan tempat. Karena itulah Islam mengatur tuntunannya dalam bidang mu'amalat dengan menetapkan prinisp-prinsip hukumnya secara umum. Prinsip hukum Islam yang menyertai dan memandu masyarakat Islam bersifat permanen dan stabil (tsawabit) dan tidak berubah sepanjang masa. Sementara perstiwa hukum dalam bidang transaksi antar manusia (mu'amalat) mengalami perubahan seiring tuntunan zaman. Karena itulah perincian sekaligus respons atas persoalan zaman diserahkan kepada pemeluknya untuk secara kreatif disusun untuk menjawab tantangan zamannya. 
Dengan asumsi dasar bahwa mu'amalat merupakan ajaran (awal) ekonomi Islam maka perpaduan antara keteguhan prinsip hukum Islam dengan keterbukaan hukum Islam dengan perubahan zaman dapat menjamin keberlangsungan ushul fikih untuk menjawab persoalan-persoalan kontemporer dalam bidang ekonomi. Untuk itulah mengkombinasikan ushul fiqh dengan alat bantu analisis dalam bidang ekonomi merupakan suatu upaya yang layak dilakukan (Muqorrobin, 2007: 10). Cukup banyak contoh dapat dikedepankan untuk membuktikan perlunya "pernikahan" ushul fikih dengan analisis ekonomi modern. Beberapa di antaranya yang relatif baru, antara lain: pertama tulisan Sami as-Suwaelem (2000) dalam tulisanya yang berjudul "Towards an Objective Measure of Gharar in Exchange"; kedua karya Mohammed Obaidullah (tt) yang berjudul "Ethics and Eficiency in Islamic Stock Markets"; ketiga Muhammad Fahim Khan (2003: 45-52) yang berjudul "Guaranteeing Invesment Deposits in Islamic Banking System"; keempat, karya Seif al-Din I Taj el-Din (1422/2004: 3-29) yang berjudul "Towards an Islamic Model of Stock Market". Keempat karya tulis tersebut mendemontarsikan bagaimana ushul fikih masih digunakan sebagai metodologi dan disandingkan dengan analisis ekonomi kontemporer.

\section{Penutup}

Dari awal hingga akhir dapat disimpulkan bahwa ushul fikih memiliki posisi yang signifikan dalam ekonomi Islam. Dalam hal ini ushul fiqh dapat memerankan fungsi metodologis. Fungsi metodologis ushul fiqh tampak manakala memperhatikan ushul fiqh yang berperan sebagai prosedur yang memandu dan mengantar para penemu hukum Islam untuk tiba pada hukum Islam. Dalam konteks ekonomi Islam peran metodologis tersebut tampak terlihat dengan jelas manakala memperhatikan pertimbangan para ulama ketika memastikan beberapa praktek ekonomi dalam kehidupan masyarakat Muslim. Kritik terhadap peran ushul fikih mesti diterima dengan merevitalisasinya melalui pemaksimalan kembali fungsinya dengan mengajak peran ilmu lain untuk "disinergikan" dengan ushul fikih.

Wallahu A'lam bish-Shawab. 


\section{Daftar Pustaka}

Abu Zahra, Muhammad. Tt. Ushul al-Figh. Mesir: Dar al-Fikr al-'Arabiy. Ahmad, Ausaf dan Kazim Raza Awan, (Ed.). 1992. Lectures in Islamicc Economics Jeddah: IRTI -IDB.

Azizy, A. Qodri. 2004. Membangun Fondasi Ekonomi Ummat. Yogyakarta: Pustaka Pelajar.

Abu Zahra, Muhammad. Tt. Ushul al-Figh. Mesir: Dar al-Fikr al-'Arabiy. Amidi, Saifuddin al-. 1984/1408. al-Ihkam fi Ushul al-Ahkam. Beirut: Dar alKitab al-'Arabi, I.

Bagus, Lorens. 1996. Kamus Filsafat. Jakarta: Gramedia.

Dahlan, Abdul Aziz (Editor). 1997. Ensiklopedi Hukum Islam. Jakarta: PT Ichtiar Baru Van Hoeve, I.

Djazuli, A. 2006. Kaidah-kaidah Fikih, Kidah-kaidah Hukum Islam dalam Menyelesaikan Masalah-Masalah Praktis, Jakara: Kencana.

Duwalibi, Muhmamad Ma'ruf ad-. 1965/1385. al-Madkhal Ila 'Ilm Ushul alFigh. Mesir: Dar al-Malayin.

Dwi, Gemala. dkk. 2006. Hukum Perikatan Islam di Indonesia. Jakarta: Kencana Prenada Media Gorup.

Gazzali, Abu Ishaq al-.1322. al-Mustashfa min 'Ilm al-Ushul. Mesir: Mathba'ah al-Airiyah. I.

Haneef, Mohamed Aslam. 2006. Pemikiran Ekonomi Islam Kontemporer. Analisis Komparatif Terpilih. Surabaya: Airlanga University Press.

Jauziyah, Ibnu Qayim al-. I'lam al-Muwaqi'in 'an Rab al-'Alamin. Beirut: Dar al-Fikr. tth. III.

Kahf, Monzer. 1995. Ekonomi Islam Telaah Analitik terhadap Fungsi system Ekonomi Islam. terjemahan Machnun Husein. Yogyakarta: Pustaka Pelajar.

Khalaf, Abdul Wahhab. 1972. 'Ilm Ushul al-Figh, Jakarta: al-Majlis al-A'la al-Indunisi lid-Da'wah al-Islamiyah.

Majma' al-Lughah al-'Arabiyah. 1979. al-Mu'jamal-Falsafiy, Kairo: al-Haiah al-'ammah li Syu' un al-Mathabi' al-Amiriyah. 
Mannan, M.A. 1986. Islamic Economics: Theory and Practice. New Delhi: Idarat Delhi.

Muqorrobin, Masyhudi. 2007. "Methodology of Economic: A Comparative Study Between Islam and Conventional Perspectif", Paper untuk Perkuliahan Program S3 Ekonomi Islam, Program Pascasarjana UIN Sunan Kalijaga Yogyakarta.

Naqvi, Syed Nawab Heider. 1994. Islam, Economics and Society, New York: Kegan Paul International.

Nadwi, 'Ali Ahmad an-. 1986/1406 H. al-Qawa'id al-Fighiyyah Mafhumuha Nasyatuha, Tathawwuruha Dirasat Muallafatiha Adillatuha Mahammatuha Tathbiqatuha, Damaskus: Dar al-Qalam.

Nasyar, 'Ali Syami an-. 1984/1404. Manahij al-Bahts 'ind Mufakiril Islam waktisyafal-Manhaj al-'Ilmi fil 'Alam al-Islami. Beirut: Dar an-Nahdlah al-'Arabiyah.

Obaidullah, Mohammed. tt., "Ethics and Eficiency in Islamic Stock Markets" dalam International Journal of Islamic Financial Services, Vol. 3. No. 2.

Pradja, Juhaya M. 1993. Filsafat Hukum Islam, Bandung: Piara, 1993.

Qaradlawi, Yusuf al-. 1985. Al-Ijtihad fisy-Syariah al-Islamiyyah ma'a Nazharat Tahliliyyah fil Ijtihad al-Mu'ashir. Kuwait: Dar al-Qalam.

Sumpena, Ilyas Sumpena dan M. Fauzi. 2002. Dekonstruksi dan Rekonstruksi Hukum Islam. Yogyakarta: Gama Media.

Suwaelem, Sami as-. 2000. "Towards an Objective Measure of Gharar in Exchange" dalam Islamic Finance Studies, Vol. 7 No. 1 dan 2 Oktober 1999-April 2000.

Surjasumantrin, Jujun. 1982. Filsafat Ilmu Sebuah Pengantar Populer. Jakarta: Sinar Harapan.

Suyuthi, as-. t.t. Al-Asybah wan-Nazhair, t.tp. Maktabah Nur Asiya.

Syafei, Rahmat. 2007. Ilmu Ushul Fiqih, Bandung: Pustaka Setia.

Syathibi, Abu Ishaq asy-. 1341 H. Al-Muwafqat fi Ushul asy-Syari'ah, Beirut: Dar al-Fikr, II.

Syaukani, asy-. 1993/1413. Irsyad al-Fuhul Ilaa 'Ilm al-Ushul, Makkah: alMaktabah at-Tijariyah. 
Taj el-Din, Seif al-Din I. 1422/2004. "Towards an Islamic Model of Stock Market" dalam J. KAU Islamic Econ, Vol. 14, hal. 3-29.

Thariqi, Abdullah Abdul Husain ath-. 2004. Ekonomi Islam Prinsip Dasar dan Tujuan. Terjemahan M Irfani Shofwani, Yogyakarta: Magistra Insania Press.

Tim Dosen Filsafat Universitas Gadjah Mada. 2002. Filsafat Ilmu Sebagai Dasar Pengembangan Ilmu Pengetahuan, Yogyakarta: Liberty Yogyakarta.

Suharto, Ugi. 2005. “Fondasi Epistemologi untuk Dispilin Ekonomi Islam", makalah disampaikan dalam Seminar Workshop Pondasi Epistemologi untuk Ilmu Ekonomi, Universitas Muhammdyah Yogyakarta, 11 April 2005.

Zaman, Hasanuz. 1984. Economic Function of an Islamic State, Leicester: The Islamic Foundation.

Zuhayli, Wahbah Az-. 1986. Ushul al-Figh al-Islamiy. Beirut: Dar al-Fikr, I. 